\title{
DETERMINING THE LEVEL OF COMPETITIVENESS AND FINANCIAL CAPACITY OF THE INSURANCE COMPANY
}

\author{
Galyna Azarenkova, ${ }^{1}$ Olena Golovko, ${ }^{2}$ Kate Piddubna, ${ }^{3}$ \\ DMYTRO POLUREZOV ${ }^{4}$
}

\footnotetext{
The Kharkiv Institute of State Higher Educational Institution "University of Banking" Kharkov, 61115, Severin Potocki Street, 12, 32, UKRAINE

1e-mail: azarenkova@khibs.edu.ua

${ }^{2}$ e-mail: elena_golovko@list.ru

${ }^{3}$ e-mail: ekaterina.poddubnaia@gmail.com

${ }^{4}$ e-mail: d.polurezov@gmail.com

RECEIVED

ACCEPTED

JEL

CLASSIFICATION

KEYWORDS

ABSTRACT

13 February 2017

15 April 2017

C25

financial potential, competitiveness, insurance, market of insurance, analysis, design

In the conditions of economic and political in stability there is a necessity of analysis the criteria of financial potential and competitiveness in a country.

A role of financial potential and competitiveness for insurance company is special, in fact during the realization of service insurance company pays bonus and expects that in the future at the offensive of accident a company fully or partly compensatesloss. In connection with the high degree of vagueness of insurance market in the every day activity insurance companies must take in to account influence of various factors of internal and external environment, that especially characteristically for the crisisstate of economy.

The article is devoted to the actual problem - analyzing the insurance market of Ukraine on the example of an insurance company and search the directions of increasing financial potential and competitiveness. The object of study is indexes of insurance company in market conditions, the subject of the study - the financial potential and competitiveness as an indicator of development of insurance company.

Methods - systematic approach, methods of economic and financial analysis, methods of modeling. The main results of the research: analyze of indexes that in fluence on financial potential and competitiveness of insurance company; the model of influence of factors is built on activity of insurance company; administrative conclusions are offered for the increase of financial potential.
} 


\section{Introduction}

World experience confirms that one of approaches of successful improvement of financial management system for insurance company is improvement of its financial potential and competitiveness. However, methods of management in Ukrainian insurance companies don't reach necessary level. Recently, the question about financial potential and competitiveness of insurance company gains the increasing relevance. Among researchers who tried to solve problems of financial potencial and competitiveness of insurance company, it is necessary to allocate V.D. Bazilevich's works, I.O. Blanca, N.M. Vnukova, Y.B. Ivanov, M.O. Kizim, J.J. Lambin, L. I. Piddubna, K.V. Shelekhova, E.A. Utkina and others. At the same time, it should be noted that the technique of determination of financial potencial is developed insufficiently.

The target of this research is to identify how to improve the management of financial potential and competitiveness in insurance company.

For the purpose to improvement the management of finance in insurance companies is necessary to pay more attention on financial potential and level of competitiveness. Financial potential has to represent a component of all-economic planning of insurance company. Financial potential and level of competitiveness have to be directed on coordination the activity of all departments of financial structure in insurance company. The financial relations and financial resources have to be the main object. Financial potential and level of competitiveness will give the chance to consider and compare possible alternative options of financial strategy in insurance company and to provide achievement of constant market positions and a financial position on this base. These indicators will provide a choice of the priority directions of development in insurance company on the basis of coordination of the different purposes and possible ways of their achievement.

\section{Analysis of financial potential of insurance company}

Let's analyze the financial potential (FDP) of the insurance company "AXA Insurance" by the method that is recommended by the National Commission for State Regulation of Financial Services Markets.

Private Joint Stock Company "Insurance Company" AXA Insurance" - one of the leaders in the market of life insurance in Ukraine. It has been represented in the Ukrainian insurance market since 2007, as part of an international financial group AXA (France). In 2014, AXA insurance is recognized as the best green brand worldwide. Today, in Ukraine, the company trusted by over half a million customers .

According to an internal report of the insurer for 12 months in 2015 AXA in Ukraine collected more than 1 billion USD of insurance premiums, which is $44 \%$ or by 331 million UAH more than in the previous year during the same period.

"AXA Insurance" paid for the period to its customers more than 490 million USD, an increase of $31 \%$. In 2016 IC "AXA Insurance" became the leader of the National Insurance TOP Award in two categories "Insurance payments" and "Auto".

Analysis is performed using the following formula:

$$
F D P=F E-M F N=\left(O_{\text {cap }}+I R\right)-\left(I_{\text {pay }}+T C\right)
$$

FDP - financial development potential,

$F E$ - financial enrichment,

MFN - moment financial needs, 


$$
\begin{aligned}
& O_{\text {cap }} \text { - own capital, } \\
& I R \text { - insurance reserves, } \\
& I_{\text {pay }} \text { - insurance payments, } \\
& T C \text { - total costs. }
\end{aligned}
$$

The financial potential of "AXA Insurance" is calculated by the following data (Table 1).

Table 1. The data for the calculation of financial capacity of "AXA Insurance" (2012-2015 years)

\begin{tabular}{lcccc}
\hline \multirow{2}{*}{ Indicator } & \multicolumn{3}{c}{ Value, UAH. } \\
\cline { 2 - 5 } & 2012 & 2013 & 2014 & 2015 \\
\hline $\mathrm{O}_{\text {cap }}$ (own capital) & 447,724 & 450,532 & 452,074 & 545,223 \\
IR (insurance reserves) & 333,796 & 373,171 & 426,971 & 508,641 \\
$\mathrm{I}_{\text {pay }}$ (insurance payments) & 363,606 & 366,207 & 368,918 & 471,254 \\
\hline $\mathrm{TC}$ (total costs) & 455,098 & 435,397 & 467,488 & 571,697 \\
\hline
\end{tabular}

Source: financial results of "AXA Insurance".

$$
\begin{aligned}
& \mathrm{FDP}_{2012}=(447,724+333,796)-(363,606+455,098)=-37,184 \mathrm{UAH}, \\
& \mathrm{FDP}_{2013}=(450,532+373,171)-(366,207+435,397)=22,099 \mathrm{UH}, \\
& \mathrm{FDP}_{2014}=(452,074+426,971)-(368,918+467,488)=42,639 \mathrm{UAH}, \\
& \mathrm{FDP}_{2015}=(545,223+508,641)-(471,254+571,697)=10,913 \mathrm{UAH} .
\end{aligned}
$$

Graphically, the dynamics of the financial capacity of "AXA Insurance" is on Figure 1.

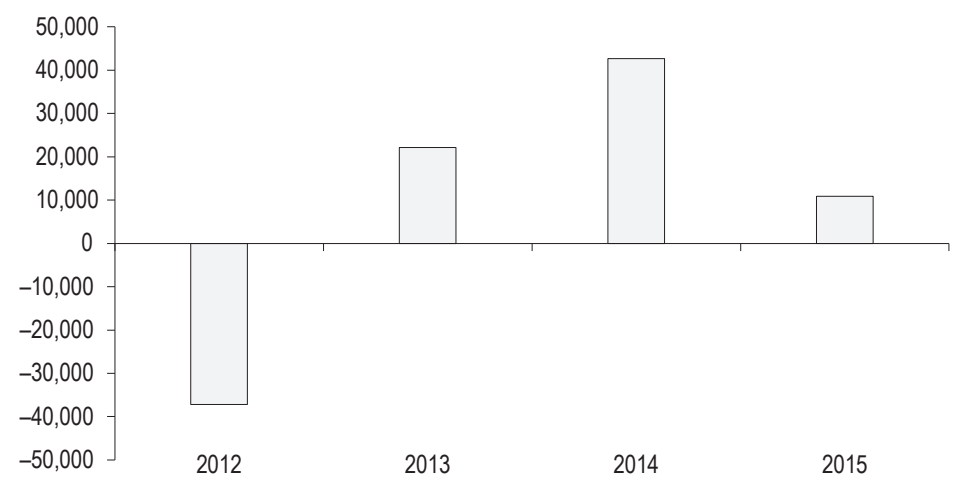

Figure 1. The dynamics of the financial capacity of "AXA Insurance" Source: financial results of "AXA Insurance".

In 2012, the value of financial potential of "AXA Insurance" was negative. But 2013 was taken certain measures to accumulate the financial resources of a larger investment, which led to a positive value of financial potential. 
In general, the financial potential of "AXA Insurance" shown a significant increase in the period from 2013 to 2014. However, in 2015 there is a decline of this indicator. This is due to regional changes of the insurance companies and the general deterioration of financial market intermediaries. To improve the financial potential it is necessary to carry out a detailed analys is of the financial costs and think about strategies to increase the financial activities.

\section{Determination of competitiveness of insurance company}

To determine the level of competitiveness of the insurance company "AXA Insurance" we should analyze its main indicator - insurance payment. It is a maximum amount that an insurance company will pay to someone who makes a claim.

Let's analyze the dynamics of insurance payments of "AXA Insurance" for the period 2009-2015 years (Table 2).

Table 2. The data for the calculation of insurance payments of "AXA Insurance" (2009-2015 years)

\begin{tabular}{ccc}
\hline Year & January-June & July-December \\
\hline 2009 & 63,206 & 197,258 \\
2010 & 168,620 & 167,800 \\
2011 & 149,475 & 145,060 \\
2012 & 185,233 & 191,848 \\
2013 & 180,312 & 199,807 \\
2014 & 178,282 & 186,258 \\
2015 & 257,666 & 232,825 \\
\hline
\end{tabular}

Source: financial results of "AXA Insurance".

For construction of trend lines, we should analyze its presence. Let's determine the mean and variance parameters. After the necessary calculations, determine that $F t a b l<F$. There is a trend in the variance.

Changes of schedules are on Figures 2-4.

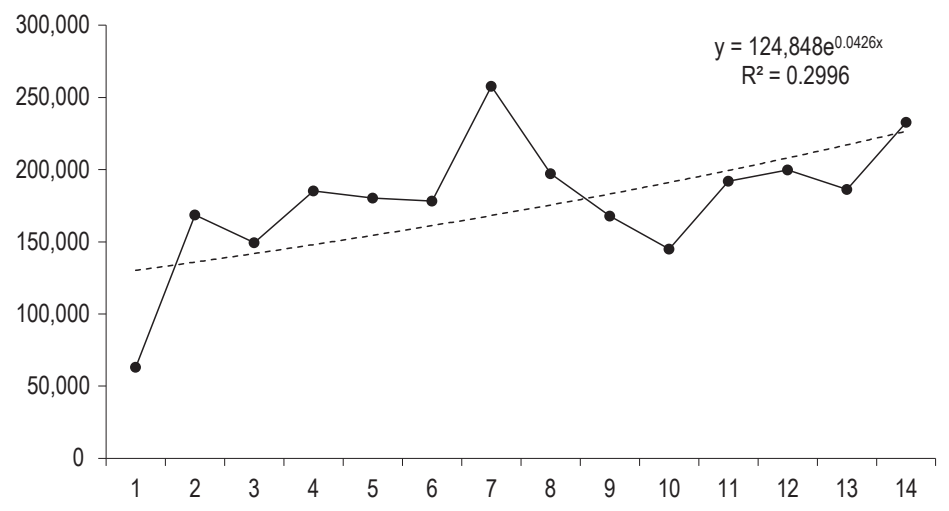

Figure 2. Exponential trend line

Sourse: financial results of "AXA Insurance". 


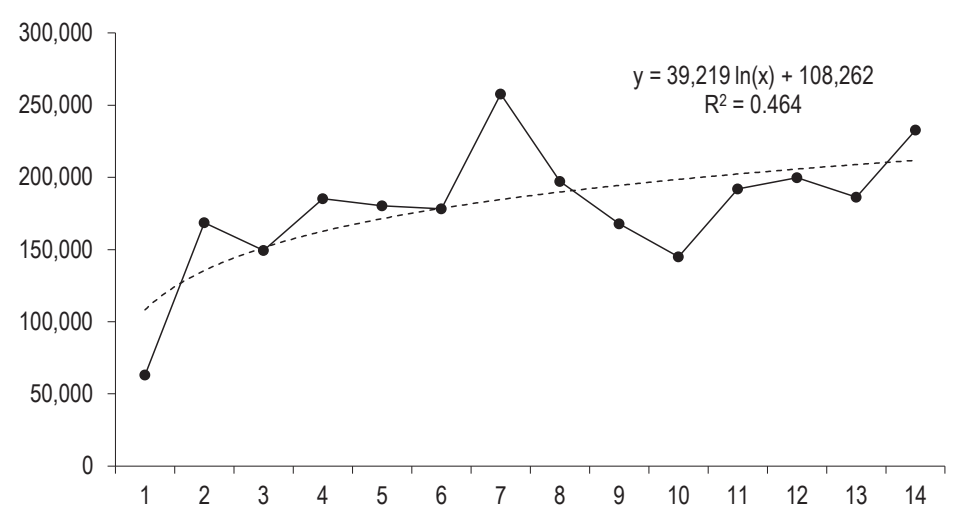

Figure 3. Logarithmic trend line

Source: financial results of "AXA Insurance".

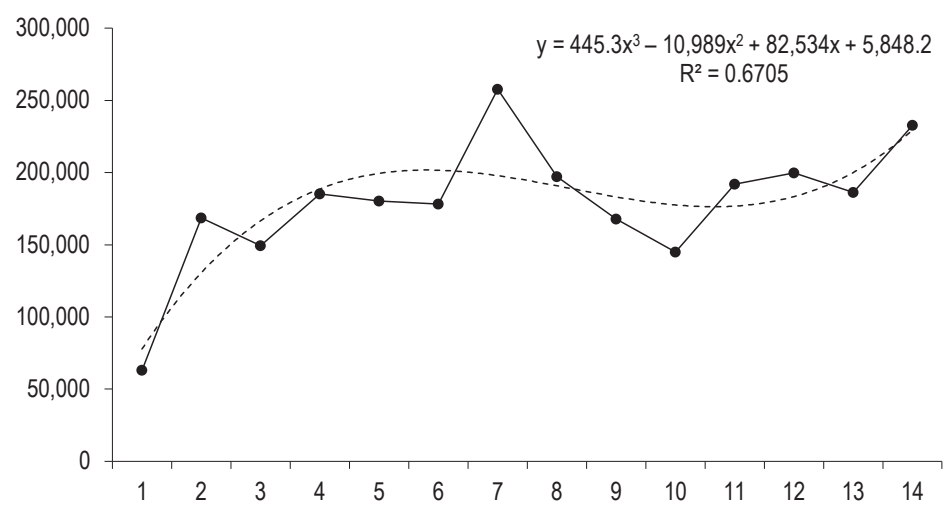

Figure 4. Polynomial trend line

Source: financial results of "AXA Insurance".

Generalizing data of all trend lines are shown in Table 3. Polynomial trend line has the highest R-squared value, so we choose it for the prediction.

Table 3. The value of the trend line functions

\begin{tabular}{cllc}
\hline No. & \multicolumn{1}{c}{ Type of themodel } & \multicolumn{1}{c}{ Equation } & \multicolumn{2}{c}{$\mathrm{R}^{2}$} \\
\hline 1. & Exponential & $\mathrm{y}=124,848 \mathrm{e}^{0.0426 \mathrm{x}}$ & 0.2996 \\
2. & Logarithmic & $\mathrm{y}=39,219 \ln (\mathrm{x})+108,262$ & 0.4649 \\
3. & Polynomial & $\mathrm{y}=445.3 \mathrm{x}^{3}-10,989 \mathrm{x}^{2}+82,534 \mathrm{x}+5,848.2$ & 0.6705 \\
\hline
\end{tabular}

Sourse: financial results of "AXA Insurance". 
To shape the dynamics of the insurance company we will build the forecast (Figure 5).

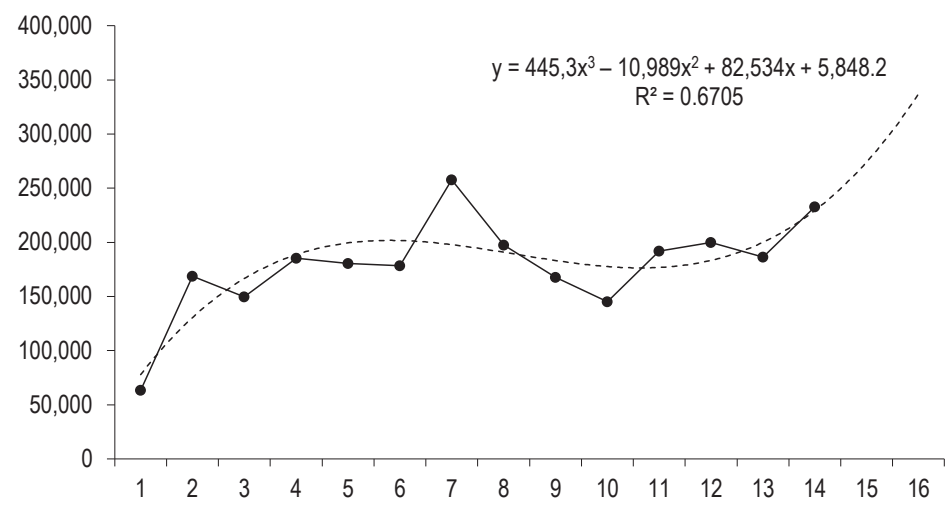

Figure 5. Predicted value of the insurance payment for the period of 2016-2017

Source: financial results of "AXA Insurance".

The research shows the growth of insurance payments. Therefore, the competitiveness of the insurance company increase. Prediction for 2016-2017 years confirms the positive trend.

To improve the financial management of insurance company, it was proposed the model classification of main groups of financial management solutions SOFIA, that was developed by M. Sorokin (Table 4).

Table 4. Model SOFIA for "AXA Insurance"

\begin{tabular}{ll}
\hline \multicolumn{1}{c}{ Criteria } & \multicolumn{1}{c}{ Decision } \\
\hline Strategic & - access to mo reprofitabl emarket segments \\
& - improving the competitiveness of the insurance market \\
& - expansion of the international financial markets \\
\hline Operations & - an increase of liquidity \\
& - reducing the cost of insurance \\
\hline Financial & - leverage in the form of short- and long-term loans \\
& - to raise funds in the form of additional issue of shares \\
\hline Investment & - modernization provided insurance services \\
\hline Analytical & - the transition to international accounting standards \\
& - international audit \\
\hline
\end{tabular}

Source: financial results of "AXA Insurance".

\section{Conclusions}

Therefore, we can conclude that the financial potential of the insurance company and its competitiveness are interrelated indicators. With their help you can get timely information about the entity and strengthen its market position. So, our task in this article was to analyze the level of competitiveness and financial potential of the company and the market using available techniques. 
Summing up, it should be noted that, unfortunately, the development of the insurance market in Ukraine is not as great as, for example, as in Europe. Its formation began relatively recently and continues to this day. With the help of foreign companies such as "AXA Insurance", we have an opportunity to study and develop the Ukrainian insurance market.

\section{References}

Insurance Company "AXA Insurance". Available at: http://axa-ukraine.com.

Mayers, D. \& Smith, C.W. (2010). Compensation and board structure: Evidence from the insurance industry. Journal of Risk and Insurance, 77 (2), 297-327.

Sorokin, М. (2005). Мастерство финансовых решений [Skill financial decisions]. Финансовый Директор [Financial Director], $9(37), 5-10$.

Wen, M.M., Martin, A.D., Lai, G. \& O'Brien, T.J. (2008). Estimating the Cost of Equity for Property-Liability Insurance Companies. Journal of Risk and Insurance, 75 (1), 101-124.

Cite this article aS: Azarenkova, G., Golovko, O., Piddubna, K., Polurezov, D. (2017). Determining the level of competitiveness and financial capacity of the insurance company. European Journal of Service Management, 22 (2), 5-11. DOI: 10.18276/ejsm.2017. 22-01. 